\title{
Croatian scientists' awareness of predatory journals
}

\author{
Ivana Hebrang Grgić ${ }^{*}$ (D) and Mihaela Guskić
}

\author{
* Correspondence: ingrgic@ffzg.hr \\ Faculty of Humanities and Social \\ Sciences, University of Zagreb, \\ Zagreb, Croatia
}

\begin{abstract}
So-called predatory journals threaten to diminish the quality of papers and of scientific research. This paper defines what constitutes a predatory journal, and provides a short literature overview. The aim of the research is to explore researchers' and librarians' awareness of predatory journals, using the example of Croatia, an EU country. Several institutions control the quality of Croatian scientific journals, so there are no predatory journals in Croatia. However, Croatian scientists publish their papers in foreign journals and thus have to be aware of all the threats of predatory journals. An online questionnaire was sent to researchers and librarians in order to find out if they understand what predatory journals are, if the researchers publish in those journals, and if the librarians educate their users about those journals. Results show that almost $90 \%$ of researchers are not sure what constitutes a predatory journal. Almost $50 \%$ of librarians are familiar with the term, but only less than $10 \%$ of librarians provide education on the topic. Raising awareness about predatory journals among scientists could prevent negative consequences such as the loss of scientific integrity and the risk of minimizing the visibility of research results. Libraries should play an important role in providing user education.
\end{abstract}

Keywords: Predatory journals, Open access, Article processing charges, Croatia

\section{$\triangle B M C$}

\section{Introduction}

Open Access (OA) publication aims to increase access by providing scholars with free online high-quality information. However, since around 2010 an unethical practice has cast a shadow over OA publications: some individuals and organizations have started publishing low-quality journals, using article processing charges (APC) as a cost model, but not controlling the quality of the papers they publish (i.e., failure to peer-review manuscripts). Those journals are usually called predatory journals, and their publishers are predatory publishers. Due to the lack of peer review, there is a high possibility of finding unethical practices in the published papers, for example falsification, fabrication, plagiarism, and guest or ghost authorship.

Scientists make up two of the most important loops in the chain of scientific communication - they are producers (i.e., authors) and users (i.e., readers) of scientific texts. Therefore, they have to choose and evaluate sources they use in their everyday work. As authors, they have to make decisions about the best journals to submit their papers to, and if they make a bad decision (e.g., if they choose a predatory journal), they risk losing credibility and prestige. Predatory journals also have a negative effect

(c) The Author(s). 2019 Open Access This article is distributed under the terms of the Creative Commons Attribution 4.0 International License (http://creativecommons.org/licenses/by/4.0/), which permits unrestricted use, distribution, and reproduction in any medium, provided you give appropriate credit to the original author(s) and the source, provide a link to the Creative Commons license, and indicate if changes were made. 
on the perception of OA. Through a lack of information literacy skills, some scientists believe that all OA journals are disreputable.

Beall (2012) was the first to use the term predatory publisher (and predatory journal) in his blog about questionable scientific journals. Until 2017, Beall had maintained a list of predatory publishers, predatory journals, hijacked journals and questionable metrics. The list was produced based on a set of criteria and was considered to be a blacklist of "bad" journals. There are opponents to Beall's definition and inclusion criteria. Some authors think that the term predatory is not appropriate and they propose other terms such as questionable journals, bad faith journals (Dupuis, 2015) or pseudo-journals (McGlynn, 2013). Additionally, many opponents think that some of Beall's criteria are wrong (e.g., Crawford, 2014) and that blacklists are not feasible solutions to the problem of unethical publishing. They prefer white lists that include journals with good practices (Berger \& Cirasella, 2015). Despite criticism, the term predatory journal is widely accepted, although sometimes used in quotation marks (Shen \& Björk, 2015). Predatory journals (and publishers) meet all three of the following criteria. They:

1. publish using an OA platform

2. use the APC model

3. do not control the quality of submitted manuscripts via a peer review process.

Many high-quality journals publish in OA mode and use the APC model. The difference between them and predatory journals is in the third criterion - controlling (or, more accurately, not controlling) the quality. Predatory journals usually claim that the papers they publish are peer reviewed, but often it is not true - they accept all manuscripts without peer review in order to make a profit. As the English language is lingua franca for today's science, predatory journals publish papers in English. That increases the chance of attracting more authors and readers that are not aware of all the dangers of predatory journals.

Although openly available, articles published in predatory journals are not indexed in reputable databases. According to Clark and Smith (2015), authors of articles in biomedical predatory journals are mostly young researchers, based in developing countries - young researchers have less publishing experience, and researchers from developing countries lack support and mentorship that is usually available in developed countries. All scientists are under pressure to publish, but those from developing countries cannot afford the high APCs. According to Clark and Smith's editorial, as well as Coney et al.'s (2018) research, predatory publishers are attractive to these authors precisely because of the lower publishing fees involved. ${ }^{1}$

Another important factor to consider in this exploration of why authors may wittingly or unwittingly submit work to a predatory journal is the concept of information literacy (IL). For Zurkowski (1974), being information literate means being able to find what is known or knowable on any subject. Information literates are people who know how to use information resources. Špiranec and Banek Zorica (2012) describe IL as a set of skills and as a social phenomenon. An important sub-set of these skills is the ability to identify predatory journals. As Croatia is a developing country, the aim of the research is to explore Croatian researchers' and librarians' awareness about predatory journals. 


\section{Scientific journals in Croatia}

There are no predatory publishers in Croatia. Croatian publishers are non-profit, publicly funded organizations (universities, associations, institutes, etc.) that publish via the OA model. Some Croatian journals publish in English (usually from the fields of natural sciences, technical sciences, and medicine), and some in the Croatian language (mostly journals from the fields of social sciences and humanities). Other journals publish in both Croatian and English. Publishing in English increases visibility of journals and authors, but publishing in Croatian is vital for language-specific terminology.

The state supports the publishing of Croatian scientific journals, and the Ministry of Science and Education defines the funding criteria (MSE, 2018). Croatian scientific journals should:

- control the quality of the papers they publish

- edit their issues according to the technical guidelines of the MSE

- publish all issues in OA, on the Hrčak portal (portal of Croatian scientific journals)

The Hrčak portal has its own inclusion criteria (Hrčak, 2018) as follows. It must:

- fulfill standard technical requirements

- publish instructions for authors

- accept international ethical standards (such as those of COPE or ICMJE)

- publish in OA (a 6 month embargo period is acceptable)

- publish the acceptance date.

The criteria ensure the high quality of Croatian journals. Quality control is mainly enacted through the traditional concept of peer review, mostly double-blind review by two peer reviewers (Stojanovski \& Marušić, 2017). Before a journal is allowed to be listed on the Hrčak portal, its editorial process (including peer review) is evaluated. Publishers are highly motivated to ensure their journals meet these stringent requirements, because most are non-commercial and need the financial support from the MSE. There are more than 450 journals on the Hrčak portal. None can be classified as predatory - all of them control quality through peer review, and a second quality check is carried out by the Hrčak team.

Croatian scientists are aware of Croatian journal quality and reliability, but they also use (as authors and as readers) international journals. That is where problems can occur - Croatian scientists are not always aware of the threat of predatory publishers. The main reason is because of a lack of sub-set information literacy skills, namely critically evaluating journal quality. According to Clark and Smith (2015), researchers from developing countries could be prone to predatory journals. Thus, librarians and researchers must clearly understand what predatory journals are in order to ensure the use of and publication in legitimate journals.

\section{Aim, sample and methodology}

Our research aims to explore Croatian scientists' and academic librarians' awareness about predatory journals. Online questionnaires with 14 questions were sent to scientists and librarians at four Croatian faculties from the fields of natural sciences and 
social sciences. We received 56 responses from scientists (25 from the field of natural sciences and 31 from the field of social sciences) and 34 responses from librarians. The questionnaire was based on Guskić (2017) Diploma thesis.

Our presumptions were:

1 Croatian scientists are not sure what constitutes a predatory journal.

2 Croatian scientists do not knowingly publish in predatory journals.

3 Librarians in Croatian academic libraries are familiar with the definition of predatory journals.

4 Librarians in Croatian academic libraries educate their users only occasionally.

\section{Results}

In the first part of the questionnaire, scientists were asked about their experiences with OA. Twenty-eight scientists from the sample (50\%) have published at least one paper in OA. The scientists are aware of publishing models, but not all are aware that all Croatian journals are in OA. Almost all the scientists (55 or 98\%) think that OA journals and repositories facilitate communication and ensure better visibility than toll-access journals and databases. One of the characteristics of Croatia as a peripheral scientific community is its economy - Croatia is a country in transition, with its economy still developing. That is why there is currently an open access publishing crisis, caused by high subscription prices, which has negatively affected Croatian scientists. To them (as perhaps other scientists and information specialists worldwide), OA seemed to be a good solution for increasing visibility of their papers.

When asked about the citation advantage of OA literature, $10.7 \%$ of the scientists do not believe it exists, $48.2 \%$ are not sure, and $41.1 \%$ believe in the advantage of OA citation. The OA citation advantage has been confirmed in many researches (e.g., Kurtz et al., 2005; Antelman, 2004; Hajjem and Harnad, 2007), but we found that more than half of the respondents are not aware of it. That implies that Croatian scientists are not familiar with all the OA advantages and possibilities.

Asked if they have ever heard of predatory publishers, 30.4\% participants responded in the negative; $58.9 \%$ respondents said they have heard of predatory publishers, but did not know much about them; and $10.7 \%$ said they do know about predatory publishers. Figure 1 shows the results for the fields of social and natural sciences. This question gives new light to previous questions: considering that the majority of scientists are not sure about what constitutes a predatory publisher, some of them may think that predatory and open access are synonyms, and thus try to avoid OA journals.

When asked if they had ever found a paper from a predatory journal in repositories or other databases they use, $57.2 \%$ answers were negative, $8.9 \%$ have found at least one predatory journal but did not warn the administrator or publisher, and $33.9 \%$ of the respondents are not sure if they have ever found a predatory journal (Fig. 2). However, if we look at the previous question, knowing that the majority of respondents are not sure about what constitutes a predatory publisher, all the negative answers to this question have to be considered with caution. The purpose of this question was to find out if the scientists think that it is important to report predatory journals to repository administrators. 


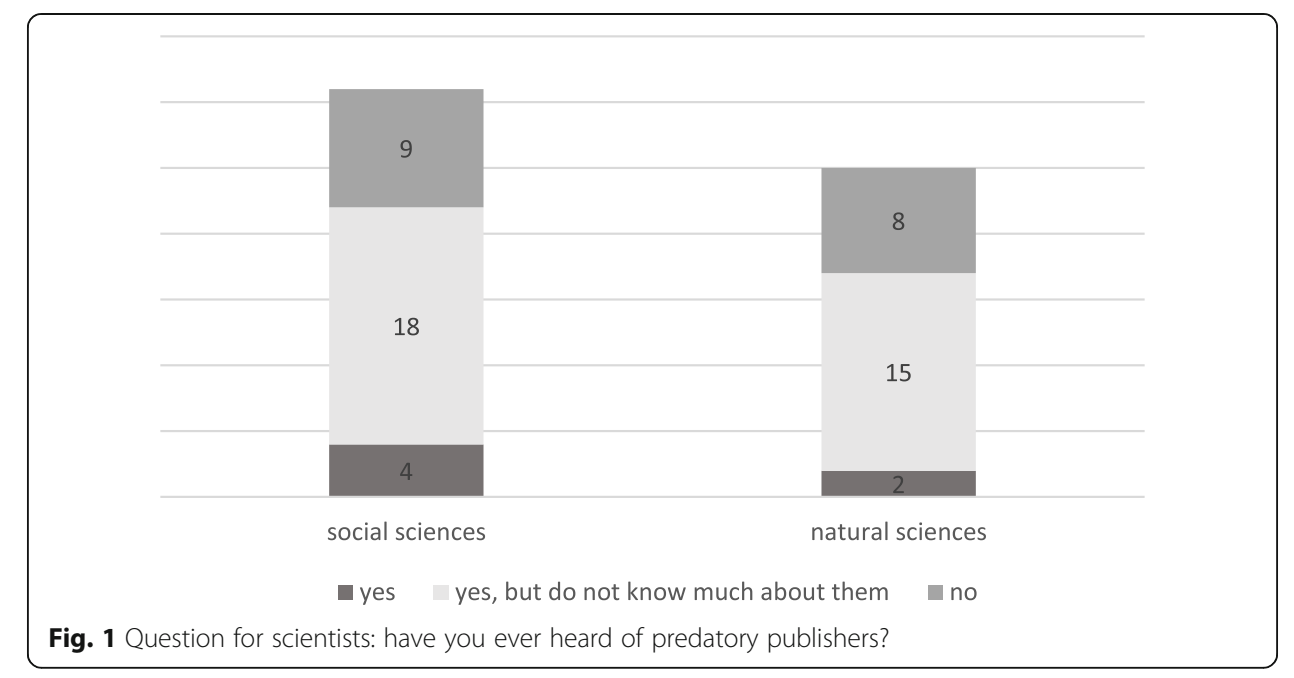

Furthermore, when asked about their publishing experiences, 94.6\% of respondents answered that they had never published a paper in a predatory journal and $5.4 \%$ are not sure. However, when asked about their colleagues' experiences, $12.5 \%$ answered that they knew about colleagues that had published in predatory journals, and $67.9 \%$ of respondents were not sure (Table 1). Again, if we know that almost $60 \%$ of the respondents are not sure what constitutes a predatory journal, the results are questionable.

The final two questions were about scientists' experiences with Croatian repositories: $33.9 \%$ of the respondents have never found a predatory journal in a Croatian catalog, and $66.1 \%$ are not sure. When asked about the possibility of finding predatory journals in Croatian repositories, $46.4 \%$ believe it is possible (Table 2). That means that almost half of the respondents do not believe that Croatian repositories (i.e., their administrators) control the quality of deposited materials. Besides the Hrčak portal (a repository with stringent inclusion criteria), there are many institutional repositories in Croatia. Administrators of those repositories are mostly librarians, i.e., information specialists that are supposed to have a high level of information literacy. They should know how to distinguish between high-quality journals and predatory journals. Even if an author

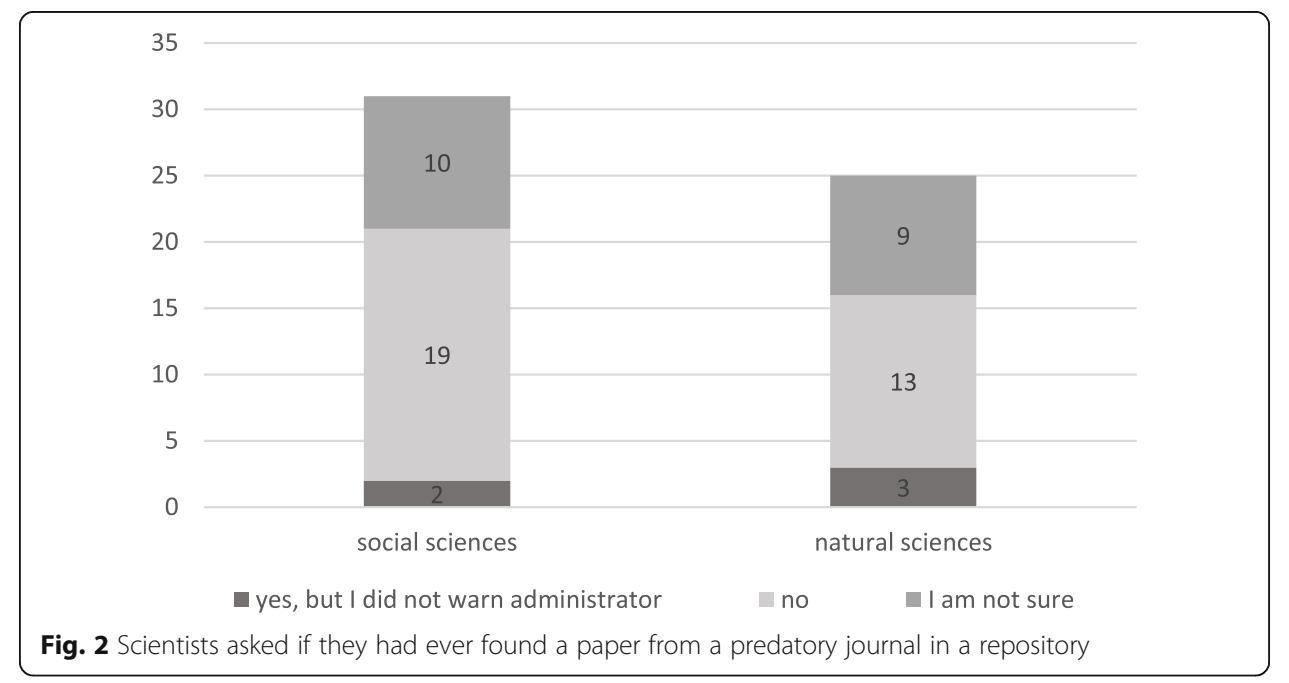


Table 1 Have some of your colleagues published a paper in a predatory journal?

\begin{tabular}{llll}
\hline Answers & $\begin{array}{l}\text { Social sciences } \\
(n=31)\end{array}$ & $\begin{array}{l}\text { Natural sciences } \\
(n=25)\end{array}$ & $\begin{array}{l}\text { Total } \\
(n=56)\end{array}$ \\
\hline Yes, but they found out the journal is predatory after publication & 2 & 2 & 4 \\
Yes, they knew the journal was predatory & 3 & 0 & 3 \\
No & 6 & 5 & 11 \\
I am not sure & 20 & 18 & 38 \\
\hline
\end{tabular}

tries to deposit a paper published in a predatory journal, administrators should intervene.

In summary, the most prominent Croatian repository, Hrčak, and the most significant funding body, the MSE, both have stringent quality control criteria in place. Therefore, it is not possible to find a predatory journal on the Hrčak portal, and the Ministry would not support such journals. Administrators, who are usually librarians, control institutional repositories at Croatian academic institutions. That should also guarantee the quality of deposited papers.

In the second part of the research, we found out that librarians are more familiar with the terms predatory publishers and predatory journals than the scientists are. Table 3 shows that more than $50 \%$ of librarians are familiar or completely familiar with the term. However, the percentage of those librarians who are not sure, or who are not familiar with the term is still too high: librarians are information specialists that should know about such practices in scientific communication, and they should educate their users on how to evaluate information.

The next question shows that only $8.8 \%$ of librarians initiate education about predatory publishers and $32.8 \%$ think that the education is not necessary (Table 4 ). The attitude may be based on the trust Croatian librarians have in the quality of Croatian journals and repositories, but Croatian scientists also use international journals, repositories and other databases that can be of questionable quality. Additional research (Hebrang Grgić, 2016) shows that, although Croatian academic librarians recognize predatory publishers as a threat for OA, $40 \%$ do not plan any form of education on OA literacy (a sub-set of information literacy skills connected with the OA publishing model). One of the reasons is because of a lack of library staff and space.

\section{Discussion}

The findings show that the majority of scientists have heard about predatory journals but are not sure how to identify them. That confirms the first presumption (Croatian scientists are not sure about what constitutes a predatory journal). Almost all of them

Table 2 Is it possible to find predatory journals in Croatian repositories?

\begin{tabular}{lll}
\hline Answer & $\%$ & $\mathrm{n}$ \\
\hline Strongly agree & 3.6 & 2 \\
Agree & 17.9 & 10 \\
Neither agree nor disagree & 32.1 & 18 \\
Disagree & 37.5 & 21 \\
Strongly disagree & 8.9 & 5 \\
\hline
\end{tabular}


Table 3 Question for librarians - I am familiar with the term predatory journals/publishers

\begin{tabular}{lll}
\hline Answer & $\%$ & $\mathrm{n}$ \\
\hline Strongly disagree & 8.8 & 3 \\
Disagree & 14.7 & 5 \\
Neither agree nor disagree & 17.7 & 6 \\
Agree & 44.1 & 15 \\
Strongly agree & 14.7 & 5 \\
\hline
\end{tabular}

think they have never published in a predatory journal and most of them are not sure about their colleagues' experiences with predatory journals. That partly confirms our second presumption (Croatian scientists do not publish in predatory journals), however, that is based on their own opinion and further research is necessary to verify it. The analysis of Croatian repositories and databases, such as the Croatian scientific bibliography, should be done to find out if Croatian scientists publish in predatory journals and if they use them as citations in their papers.

Most of the librarians are aware of predatory journals but more than $40 \%$ are not sure about the definition. Less than $10 \%$ of librarians initiate user education. This partly confirms our third and fourth presumptions (librarians in Croatian academic libraries are familiar with what constitutes a predatory journal and they educate their users occasionally). Croatian librarians rely on the trust they have in the quality of Croatian journals and repositories, despite knowing that Croatian scientists also use international journals, repositories and other databases that could be of questionable quality. Moreover, most Croatian academic libraries are short-staffed, and do not have time to organize education. They usually act only upon user requests.

Education about how to identify predatory journals is extremely important. Librarians and researchers can use black or white lists to identify predatory journals (Berger \& Cirasella, 2015). There are concerns about blacklists - some authors think the lists are flawed due to a weak set of criteria that results in the inclusion of journals that are not predatory and the exclusion of some that are predatory (Teixeira da Silva \& Tsigaris, 2018). Other authors (Strinzel et al., 2019) conclude that both black and white lists can be helpful in identifying predatory journals.

If users have never heard of predatory publishers, there is an information void users do not ask librarians about those journals and librarians do not have time to organize any kind of education about the topic. There are many possible consequences of such practice - scientists who do not have skills to identify predatory journals will use them (either as readers or as authors) unwittingly helping to produce science of questionable quality. Scientists who do not know enough about predatory journals, might avoid OA in general, believing that all OA journals are disreputable. In addition, those scientists might agree to be editors or members of editorial boards of predatory

Table 4 Question for librarians - do you educate your users about predatory journals/publishers?

\begin{tabular}{lll}
\hline Answer & $\%$ & $\mathrm{n}$ \\
\hline Yes, I initiate education & 8.8 & 3 \\
Yes, if the users ask for it & 52.9 & 18 \\
No, it is not necessary & 38.3 & 13 \\
\hline
\end{tabular}


journals, not knowing or understanding that the journals are predatory. By doing so, they will risk their reputation and the reputation of their institutions.

\section{Conclusion}

There is high percentage of OA journals in Croatia, almost all of them available on the national portal Hrčak. The portal controls the quality of journals by evaluating the editorial process (including peer review). Therefore, there are no predatory publishers and journals in Croatia. However, Croatian scientists use international journals in their everyday work: they publish their papers in international journals and they use these journals as sources for their research. Although it was not asked in the questionnaire, it is possible that some authors think that OA equals APC and are not aware that there are OA journals that do not charge authors for publishing.

Alleged predatory journals publish all submitted papers in OA, without controlling quality, and make a profit by using the APC model. Those journals pose a serious threat to scientific communication - they are freely available and thus have a potentially high impact, especially for scientists from peripheral scientific communities with limited funds. Scientists, as authors and readers of scientific texts, should know how to evaluate scholarly journals in order to use and produce reliable information. If not, they risk their own reputation and they risk harming the reputation of their institution. Scientists as users of scientific information should also be aware of the threat of predatory journals - the information published in those journals is unevaluated, and scientists should not base their research on unreferenced information.

Croatian scientists are aware of the threat, but are not always sure how to identify predatory journals and publishers. At this point, the role of academic libraries is very important. One of their missions is to implement information literacy programs for their users: develop skills for detecting predatory journals as part of information literacy. Croatian academic librarians are mostly aware of the problem, but the education is still insufficient and mostly based on individual education or upon a user's specific request.

The sample of the survey is small, but the results indicate there is a lack of awareness among Croatian scientists (and also librarians) about the threat of predatory journals. Academic librarians are essential for educating their users about predatory journals and publishers - they should teach them how to find, evaluate and use scientific information properly by developing their information literacy skills through different forms of education (individual approach, workshops, webinars, seminars, conferences, online courses, etc.). This lack of IL skill in detecting predatory journals could increase the number of these journals, and the number of papers published in them. The result could be harmful for the OA publishing model. Raising awareness about predatory journals among scientists could prevent negative consequences such as the loss of faith in scientific integrity and a dramatic reduction in the visibility of research results.

\section{Endnotes}

${ }^{1}$ Recently, it seems that some predatory journals have increased their APCs to more closely imitate legitimate journals, although this trend is yet to be investigated.

\section{Abbreviations}

APC: Article Processing Charges; COPE: Committee on Publication Ethics; ICMJE: International Committee of Medical Journal Editors; MSE: Ministry of Science and Education; OA: Open Access 
Acknowledgments

Not applicable.

\section{Funding}

There was no funding for the current study.

\section{Availability of data and materials}

The confidentiality of the data has been preserved and the data have not been shared with any party.

\section{Authors' contributions}

IHG drafted the first part of the manuscript (literature review, sample, methodology) and conclusion. MG drafted the second part (result analysis). MG and IHG determinated the sample and the methodology for the research. MG drafted the questionnaire. MG carried out the study. Both authors participated in writing the manuscript and both authors read and approved the final version. he authors confirm that that the content of the manuscript has not been published, or submitted for publication elsewhere. Some results were presented at conference Plagiarism across Europe and Beyond, Ephesus, Turkey, 9th-11th May 2018.

\section{Competing interests}

The authors declare that they have no competing interests.

\section{Publisher's Note}

Springer Nature remains neutral with regard to jurisdictional claims in published maps and institutional affiliations.

Received: 1 December 2018 Accepted: 16 April 2019

Published online: 19 June 2019

\section{References}

Antelman K (2004) Do open access articles have a greater research impact? Coll Res Libr News 65(5):372-382 Retrieved from: http://eprints.rclis.org/5463/1/do_open_access_CRL.pdf

Beall J (2012). Predatory publishers. The Scientist, 1 August. Retrieved from: https://www.the-scientist.com/?articles.view/ articleNo/32426/title/Predatory-Publishing/

Berger M, Cirasella J (2015) Beyond Beall's list: better understanding predatory publishers. Coll Res Libr News 76(3):132-135 Retrieved from: https://crln.acrl.org/index.php/crlnews/article/view/9277/10342

Clark J, Smith R (2015) Firm action needed on predatory journals. Br Med J 350:h210 https://doi.org/10.1136/bmj.h210

Coney KD, Lalu MM, Skidmore B, Ahmadzai N, Grudniewicz A, Moher D (2018) What is a predatory journal?: a scoping review: version 2; referees: 3 approved. F1000Research 7:1001 https://doi.org/10.12688/f1000research.15256.2

Crawford W (2014) Ethics and access: the sad case of Jeffrey Beall. Cites \& Insights 14(4):1-14 Retrieved from: https:// citesandinsights.info/civ14i4on.pdf

Dupuis J (2015) Treating the disease and avoiding questionable/bad faith journals. 1 November. Retrieved from: http:// confessions.scientopia.org/2015/03/31/some-perspective-on-predatory-open-access-journals/

Guskić M (2017) Experiences with predatory journals in Croatia: diploma thesis. University of Humanities and Social Sciences. Retrieved from, Zagreb http://darhiv.ffzg.unizg.hr/id/eprint/9603/

Hajjem C, Harnad S (2007) The open access citation advantage: quality advantage or quality bias? Retrieved from: https:// arxiv.org/abs/cs/0701137

Hebrang Grgić I (2016) Information literacy and open access in Croatian academic libraries. Libr Rev 65(4/5):255-266 https:// doi.org/10.1108/LR-01-2016-0009

Hrčak (2018) Requirements for inclusion of journals in HRČAK. Retrieved from: https://hrcak.srce.hr/index.php?show= application_criteria\&lang=en

Kurtz M, Eichhorn G, Accomazzi A, Grant C, Demleitner M, Henneken E, Murray SS (2005) The effect of use and access on citations. Journal of Information Processing and Management 41(6):1395-1402 https://doi.org/10.1016/j.ipm.2005.03.010

McGlynn T (2013) The evolution of pseudojournals. 14 February. Retrieved from: https://smallpondscience.com/2013/02/14/ the-evolution-of-pseudojournals/

MSE (2018) Criteria for financial support to scientific journals and journals for the popularization of science. Retrieved from: https://mzo.hr/sites/default/files/dokumenti/2018/Znanost/Znanstvena-infrastruktura/kriteriji_za_financijsku_potporu_ znanstvenim_casopisima_i_casopisima_za_popularizaciju_znanosti.pdf

Shen C, Björk BC (2015) "Predatory" open access: a longitudinal study of article volumes and market characteristics. BMC Med 13 https://doi.org/10.1186/s12916-015-0469-2

Špiranec S, Banek Zorica M (2012) Information literacy 2.0: hype or discourse refinement. J Doc 66(1):140-153 https://doi.org/ 10.1108/00220411011016407

Stojanovski J, Marušić A (2017) Does small equal predatory?: analysis of publication charges and transparency of editorial policies in Croatian open access journals. Biochemia Medica 27(2) https://doi.org/10.11613/BM.2017.032

Strinzel M, Severin A, Milzow K, Egger M (2019) "Blacklists" and "whitelists" to tackle predatory publishing: a cross-sectional comparison and thematic analysis. PeerJ Preprints 7:e27532v1 https://doi.org/10.7287/peeri.preprints.27532v1

Teixeira da Silva J, Tsigaris P (2018) What value do journal whitelists and blacklists have in academia. J Acad Librariansh 44(6): 781-792 https://doi.org/10.1016/j.acalib.2018.09.017

Zurkowski PG (1974) The information service environment: relationships and priorities: related paper: number five. National Commission on Libraries and Information Science, WA Retrieved from: http://files.eric.ed.gov/fulltext/ED100391.pdf 